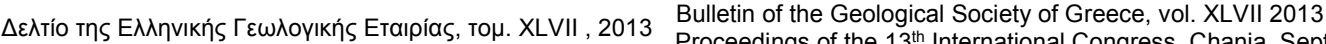

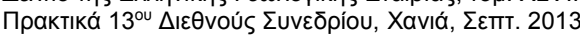
2013

\title{
CARBONATE AND ORGANIC CARBON CONTENT IN THE RECENT SEDIMENTS OF ELEFSIS BAY AS INDICATORS FOR THE PALEOENVIROMENTAL EVOLUTION OF THE SYSTEM
}

\author{
Petropoulos A. ${ }^{1}$, Androni A. ${ }^{2}$, Ntamkarelou T. ${ }^{3}$ and Anagnostou Ch. ${ }^{2}$ \\ ${ }^{1}$ National and Kapodistrian University of Athens, Faculty of Geology and Geoenvironment, \\ Department of Dynamics Tectonics \& Applied Geology, alexandrospetrop@gmail.com \\ ${ }^{2}$ Institute of Oceanography, Hellenic Centre for Marine Research, $46.7 \mathrm{~km}$ Athens-Sounio Avenue, \\ Mavro Lithari, 19013 Anavyssos, Greece, chanag@hcmr.gr,afrodite@hcmr.gr \\ ${ }^{3}$ University of the Aegean, Department of Marine Sciences tati_karinco@hotmail.com
}

\begin{abstract}
During the Holocene period Elefsis bay acted as a semi-enclosed system obstructing water circulation. In some areas, sampling has revealed the problems of anoxia that prevails in the bay, which has been worse during the summer months. Analyses undertaken in a core from the bay of Elefsis showed notable changes in carbonate and organic material, which prove the paleo-environmental evolution of the bay. Such changes of carbonate are due to the different deposition of calcium carbonate from biogenic source (probably and from inorganic source). The variation of organic carbon is still a factor of limited water circulation in the bay.

Key words: coastal paleolakes, authigenic carbonate minerals, Elefsis Bay/Greece.
\end{abstract}

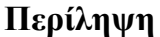

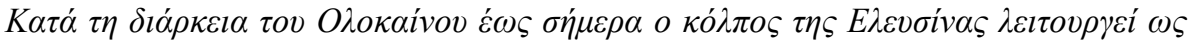

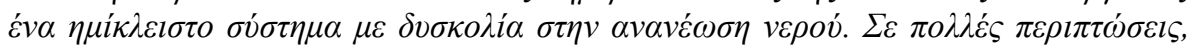

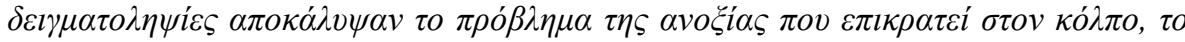

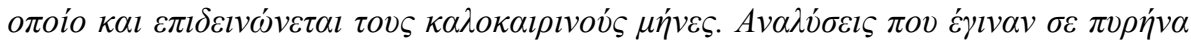

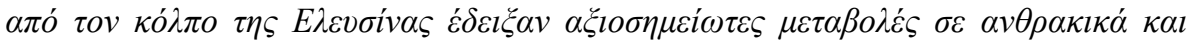

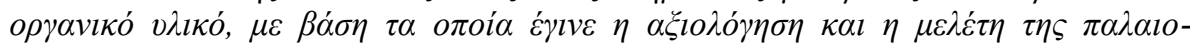

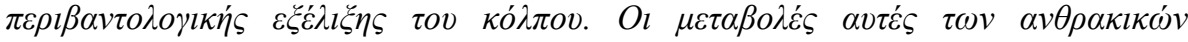

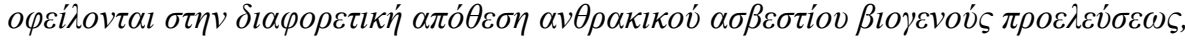

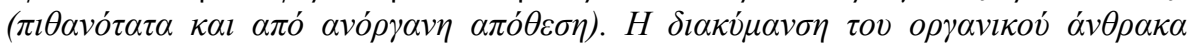

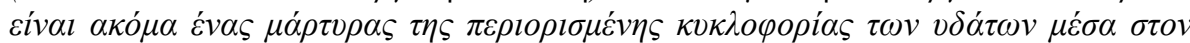

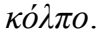

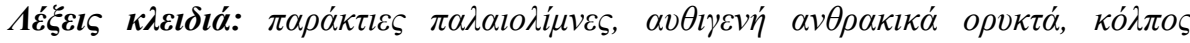
Eגevoivas. 


\section{Introduction}

Elefsis Bay is a geomorphological embayment between Attica and Salamis Island in northern Saronikos Gulf (Greece) (figure 1). It communicates through shallow straits, in west and east, with the open Saronikos Gulf. The straits show nowadays a depth of $8 \mathrm{~m}$ at the western and $12 \mathrm{~m}$ at eastern and the deepest part of the bay shows a depth of $35 \mathrm{~m}$.

The description of the sediment units of one core (S-2 PERSEUS - Saronikos) from the deepest part of the bay, as well as sediment analyses from the core, -carbonate content and carbonate mineral differentiation, organic carbon and nitrogen content,- lead to important indicators for the paleoenvironmental evolution of the Elefsis aquatic system. This paleoenvironmental evolution of the Elefsis Bay is the aim of this work.

\section{Description of the Area}

Elefsis Bay is the result of neotectonic processes leading to the fragmentation of the broader area. Two main faulting systems dominate in the area, the WNW-ESE system and the SW-NE system (Lekkas, 2001). These two systems regulate the geomorphological diversity of the extended area and consequently the configuration of the bay. The area is characterized by a small drainage basin, mainly extended in the northern part of Elefsis Bay (figure 2). Ephemeral tributaries with low fresh water input drain into the bay. They contribute also to the sedimentation processes of the bay with terrigenous sediment particles supply.

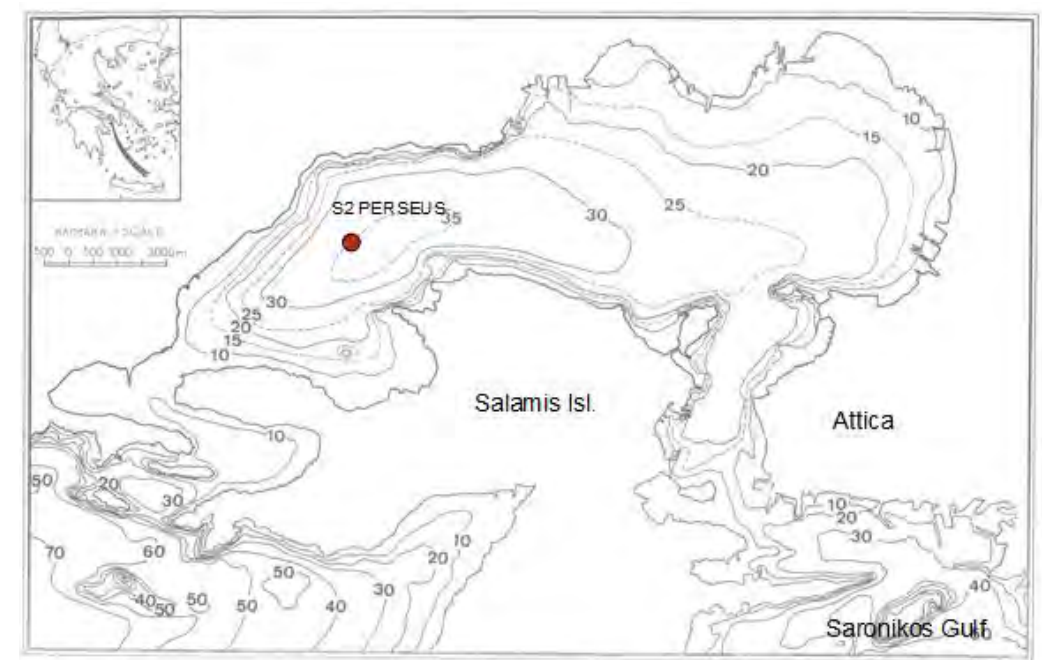

Figure 1 - Bathymetric map of Elefsis Bay (map produced by Anagnostou, unpublished data). Red spot shows the coring position of the S2 PERSEUS core.

The bathymetry of the Elefsis Bay shows an eastern part with depths of 10-25 m and a western part with depths of more than $30 \mathrm{~m}$ (s. figure 1). Systematic sub-bottom profiling indicates the thickness of the Holocene sediment cover from 3-5 $\mathrm{m}$ in the eastern part and $10-15 \mathrm{~m}$ in the western part (figure 3).

Sedimentation rate was estimated for the recent sediments in the western part of the bay and shows values of approximately $3 \mathrm{~mm} /$ year (Hatzianestis et al., 2004).

The Elefsis ecosystem dynamic is summarized in the work of Pavlidou et al., 2010. The low freshwater input and the limited water mass exchange with the Saronikos system resulted to periodical anoxic events (s. Pavlidou, et al., 2010). 


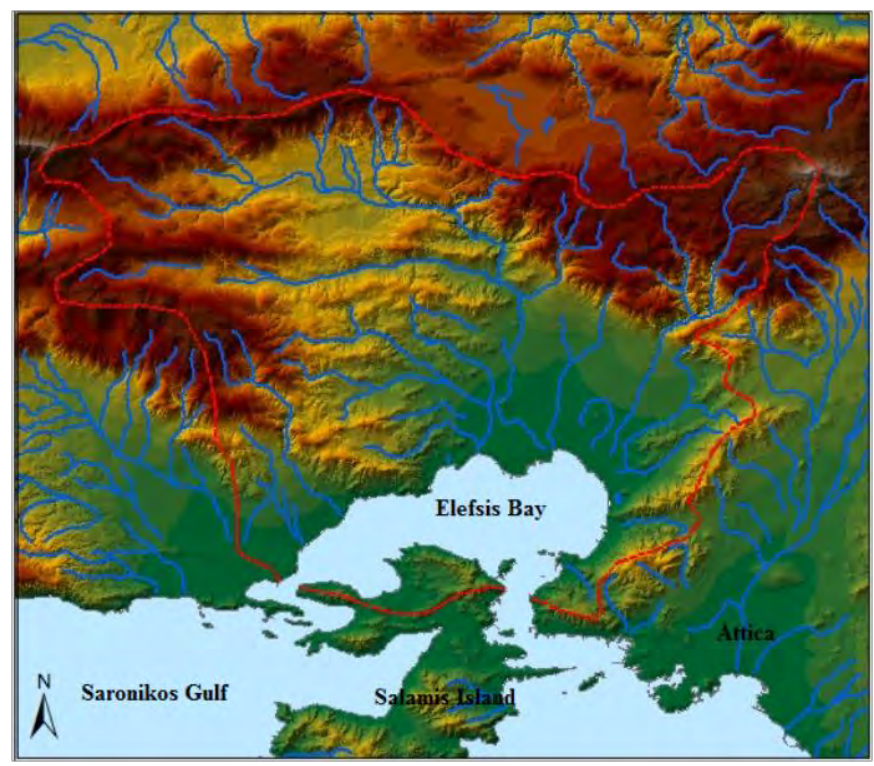

Figure 2 - The drainage area of the Elefsis Bay (red line).
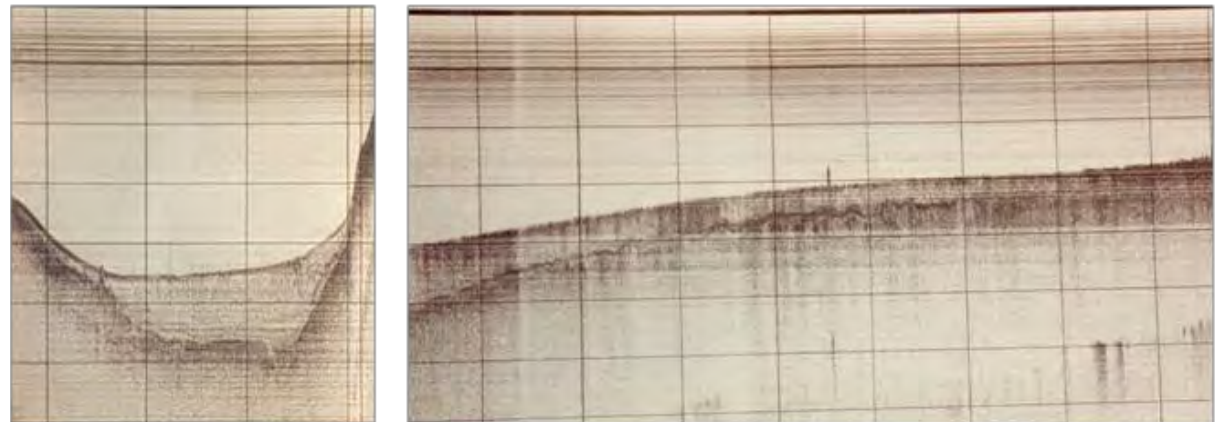

Figure 3 - Sub-bottom profiles of the Elefsis Bay. They show clear the Holocene marine sediment cover and the pre-depositional unconformity, Left: The Holocene sediments in the western part of Elefsis Bay with a thickness of 8-13 m. Right: A 3-5 m thickness of the Holocene sediment cover in the eastern part of the bay.

\section{Methodology}

During a research cruise in Elefsis Bay, in February 2012, a sediment core was extracted from the deepest part of Elefsis basin, means of a $5 \mathrm{~m}$ long gravity core, using R/V Aegaeo of the Hellenic Center of Marine Research (HCMR). Longitudinally splitting of the core, picturing, macroscopic description (the color was determined using the Standard Soil Color Charts) and sub-sampling are carried out in the laboratories of HCMR. The sub-sampling is designed for sedimentological, geochemical and micropaleontological analyses.

For the purposes of this work sediment samples were powdered in a Fritch agate mortal mill for 10 minutes after drying in $60-65^{\circ} \mathrm{C}$ for at least 24 hours.

For the total carbon, organic carbon and organic nitrogen a CHN Analyzer is used. Successful determination of organic carbon relies upon the separation of organic from inorganic carbon. For this reason the sediment samples are separated in two parts, in the one the removal of inorganic forms is achieved by acidification, in the other one the quantity of total carbon and nitrogen is 
determined. The amount of inorganic carbon is resulted from the difference of the above ones. A small amount is weighted (10-15 mg) in silver weighing pans for organic carbon determination and tin pans for total carbon and nitrogen determination. The sediments which are weighed in tin pans are closed, compacted and formed into a ball in order to be transferred into CHN-analyzer auto sampler. The sediments that are weighed in silver pans are acidified carefully. After the acidification and the drying at $60^{\circ} \mathrm{C}$ overnight the sediment samples are closed and compacted. Flash EA (1112 Series) CHN-analyzer by Thermo Scientific is used for the determination of carbon and nitrogen (Direction Limits for TC is $<5 \mu \mathrm{gC}$ and for $\mathrm{TN}$ is $<2 \mu \mathrm{gN}$ ). Data acquisition, integration and handling are performed by the EAGER 300 software.

From the inorganic carbon the carbonate content of these sediments is calculated. Carbonate mineral proportions were semi quantitative determined by X-ray diffraction (XRD) using a Rigaku $\mathrm{D} / \mathrm{MAX} \mathrm{B}$ X-ray diffractometer fitted with a $\mathrm{CuK} \alpha_{1}$ radiation tube, goniometer and a graphite monochromator. Instrument settings were standardized usually at $40 \mathrm{kV}$ and $20 \mathrm{~mA}$.

Samples for scanning electron microscope (SEM) study were carbon -coated in Baltec sputter coater.

\section{Results}

Macroscopic description of the sediment core: The sediment core was extracted from the deepest part of the Elefsis basin in a depth of $35 \mathrm{~m}$ [Gravity core S2-Perseus Saronikos ( figure1). The length of the sediment core is $342 \mathrm{~cm}$. The macroscopic description shows a differentiation of the sediment depositions in five main units (A, B, C, D, E). In Table I the description of the core is presented. The dominated sediment type is mud. The sand content, the biogenous debris and the color differentiate the sediment depositions. Remarkable is the fine layer D $(298-300 \mathrm{~cm})$, which shows a dark color and coarser sand particles, gradated in coarser grains at the basis of the fine layer going progressively to finer grains upwards.

Table 1 - Description of core S-2.

\begin{tabular}{|c|c|c|c|}
\hline \multicolumn{4}{|c|}{$\begin{array}{l}\text { Extraction of the GRAVITY CORE S-2 PERSEUS SARONIKOS [09 February 2012] } \\
\text { Position: } 38^{\circ} 00.50 \mathrm{E}, 23^{\circ} 27.48,00 \mathrm{~N} \text {, Depth } 35 \mathrm{~m}\end{array}$} \\
\hline \multicolumn{4}{|c|}{ Opening and descriptions day Thursday 08 March 2012} \\
\hline Main Units & & $\begin{array}{l}\text { Finer } \\
\text { description }\end{array}$ & \\
\hline A 000-192 cm & $\begin{array}{l}\text { light olive gray - olive gray } \\
\text { mud + biogenous debris }\end{array}$ & $\begin{array}{l}00-03 \mathrm{~cm} \\
03-92 \mathrm{~cm} \\
92-192\end{array}$ & $\begin{array}{l}\text { black mud } \\
\text { light olive-gray mud with shell } \\
\text { fragments } \\
\text { olive-gray mud with shell fragments } \\
\text { (192 sharp color boundary) }\end{array}$ \\
\hline B $192-231 \mathrm{~cm}$ & gray clay & & gray clay \\
\hline C $231-298 \mathrm{~cm}$ & $\begin{array}{l}\text { alteration of mud and sandy } \\
\text { mud layers, color } \\
\text { differentiation from pelow } \\
\text { yellow, light gray, gray }\end{array}$ & $\begin{array}{l}231-234 \mathrm{~cm} \\
234-236,5 \mathrm{~cm} \\
236,5-241 \mathrm{~cm} \\
241-249 \mathrm{~cm} \\
249-251 \mathrm{~cm} \\
251-257,5 \mathrm{~cm} \\
257,5-262 \mathrm{~cm} \\
262-282 \mathrm{~cm} \\
\\
282-288 \mathrm{~cm} \\
288-298 \mathrm{~cm}\end{array}$ & $\begin{array}{l}\text { pelow yellowish mud } \\
\text { gray mud with biogenous fragments } \\
\text { gray mud with biogenous fragments } \\
\text { pelow yellowish grey clay } \\
\text { gray mud } \\
\text { light gray mud } \\
\text { gray mud } \\
\text { olive gray mud (two fine layers, } \\
\text { thickness } \sim 1 \mathrm{~cm} \text { in } 276-277 \mathrm{~cm} \text { and } \\
281-282 \mathrm{~cm}) \\
\text { olive gray mud } \\
\text { brownish gray mud }\end{array}$ \\
\hline D $298-300 \mathrm{~cm}$ & black sandy mud (organic) & & [sharp color boundary, transgression?] \\
\hline E $300-342 \mathrm{~cm}$ & $\begin{array}{l}\text { Gray sandy mud (biogenous } \\
\text { debris) }\end{array}$ & & \\
\hline
\end{tabular}


The lithological characteristic of the core and the color differentiation along the core are figured in the figure 4. Color photos of the core attach also the lithological description. At the right side of the lithology column the subsampling places of the core are signalized. The exact sample of sampling is seeing in table 2. Two macroscopic marks allow a differentiation of three stratigraphic sections (figure 6). Starting from the bottom the third stratigraphic section extends from 300 to 342 $\mathrm{cm}$ (description unit E). The fine sand horizon $(298-300 \mathrm{~cm})$ forms the boundary to the next stratigraphic section. These fine horizons signalize probably a transgression layer. Color differentiation is used to separate the next stratigraphic section upwards. The intermediate second stratigraphic section extends from 192 to $300 \mathrm{~cm}$ (description units B, C, D) and it is characterized by mud sediment type and lighter colors. The sharp color line at $192 \mathrm{~cm}$ forms the boundary of this stratigraphic section to the next one, to the more recent one. The younger stratigraphic section is characterized by dark colored mud and extends from the surface to $192 \mathrm{~cm}$ in the core.

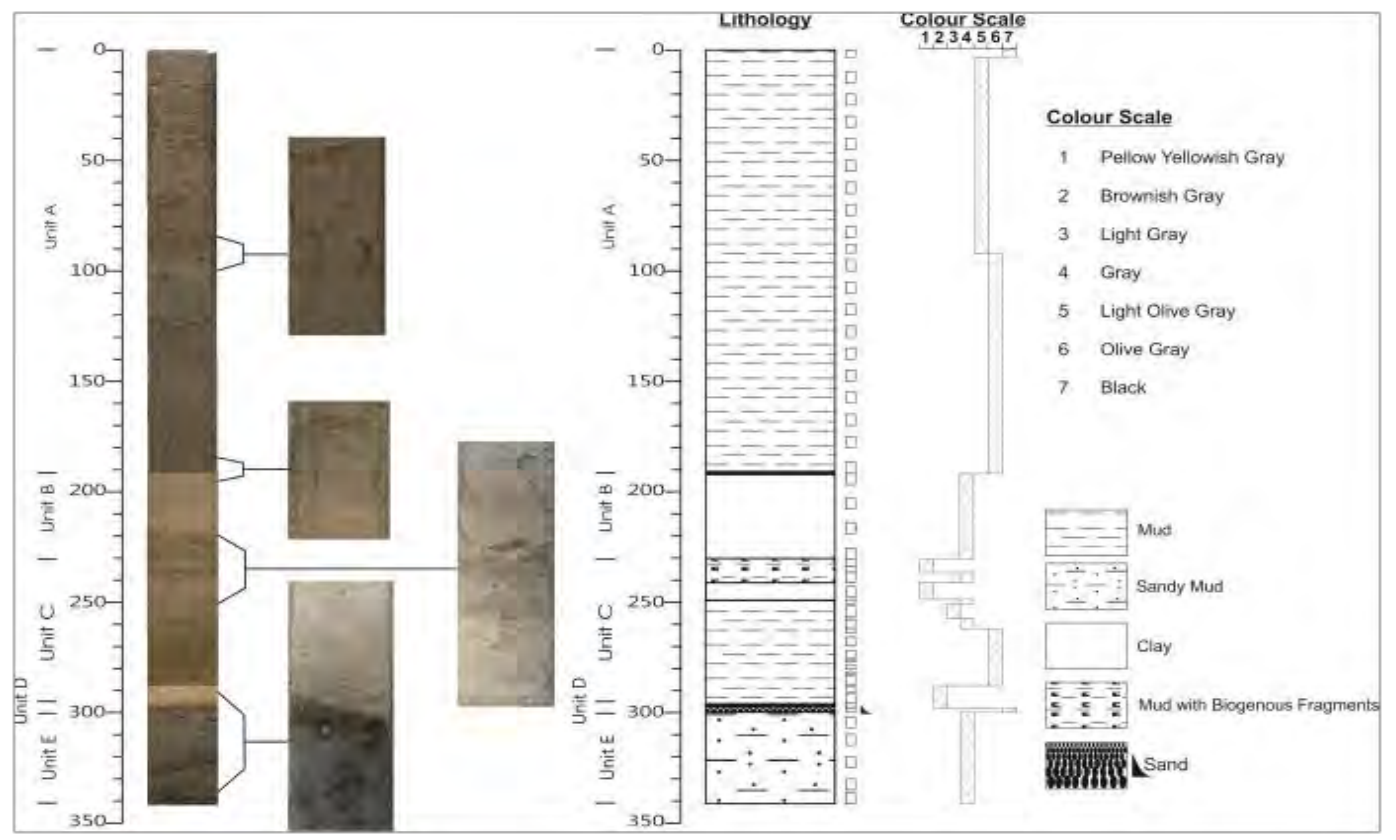

Figure 4 - Macroscopic description of the core S2 Perseus - Saronikos. The left part of the figure is covered by a synthesis of photos showing the whole core as well as by photos showing some important details of the core. The right part of the figure shows the sediment characteristics of the core and its color variation.

Carbonate, organic carbon and nitrogen content distribution: Using CHN-Analyzer in 46 samples the carbonate, organic carbon and nitrogen contents are measured. In the Table 2 the results of the measurements are given. The carbonate content values show a fluctuation from $36,87-85,82 \%$, the organic carbon content from 0,257 to $2,676 \%$, with an average value of $1,249 \%$, and the total nitrogen from 0,017 to $0,160 \%$, with an average value of $0,84 \%$. In the Table 2 are also the values of the calculated $\mathrm{C} / \mathrm{N}$ ratios included.

The vertical distribution of the carbonate content as well as of the organic carbon and nitrogen content are showed in figure 5. Looking at the vertical distribution of the carbonates we can differentiate the deepest stratigraphic section with relative low carbonate values $(35,84-51,93 \%)$, the intermediate stratigraphic section with higher carbonate values $(59,14-85,82 \%)$ and the younger stratigraphic section with relative lower carbonate values $(36,87-59,35 \%)$. We can also recognize the same trends if we look at the organic carbon and the total nitrogen distribution. 
Table 2 - Results of the measurements of carbonate, organic $C$ and total nitrogen content.

\begin{tabular}{|c|c|c|c|c|c|c|c|c|c|}
\hline $\begin{array}{l}\text { Sample } \\
\text { (Elefsis } \\
\text { S2) }\end{array}$ & $\begin{array}{l}\text { Carbonate } \\
\text { content } \%\end{array}$ & $\begin{array}{l}\text { Organic } \\
\text { carbon } \\
\%\end{array}$ & $\begin{array}{l}\text { Total } \\
\text { N\% }\end{array}$ & $\begin{array}{l}\mathrm{C} / \mathrm{N} \\
\text { ratio }\end{array}$ & $\begin{array}{l}\text { Sample } \\
\text { (Elefsis } \\
\text { S2) }\end{array}$ & $\begin{array}{l}\text { Carbonate } \\
\text { content } \%\end{array}$ & $\begin{array}{l}\text { Organic } \\
\text { carbon } \\
\%\end{array}$ & $\begin{array}{l}\text { Total } \\
\text { N\% }\end{array}$ & $\begin{array}{l}\mathrm{C} / \mathrm{N} \\
\text { ratio }\end{array}$ \\
\hline $0-3$ & 36,87 & 1,870 & 0,160 & 11.672 & $226-231$ & 64,15 & 1,695 & 0,127 & 13.315 \\
\hline $10-15$ & 42,00 & 1,006 & 0,089 & 11.318 & $231-234$ & 75,24 & 1,481 & 0,110 & 13.413 \\
\hline $20-25$ & 47,47 & 0,795 & 0,070 & 11.290 & $234-236$ & 73,28 & 1,690 & 0,130 & 12.967 \\
\hline $30-35$ & 43,12 & 0,781 & 0,072 & 10.787 & $236-241$ & 76,46 & 1,475 & 0,101 & 14.552 \\
\hline $40-45$ & 42,71 & 0,785 & 0,071 & 11.042 & $243-248$ & 78,29 & 1,69 & 0,091 & 18.486 \\
\hline $50-55$ & 41,82 & 0,729 & 0,065 & 11.148 & $249-251$ & 78,16 & 1,784 & 0,112 & 15.995 \\
\hline $60-65$ & 40,37 & 0,706 & 0,064 & 11.083 & $252-257$ & 81,79 & 2,190 & 0,129 & 17.029 \\
\hline $70-75$ & 40,55 & 0,738 & 0,066 & 11.218 & $258-262$ & 82,30 & 2,351 & 0,132 & 17.754 \\
\hline $80-85$ & 39,59 & 0,716 & 0,063 & 11.409 & $262-264$ & 82,66 & 2,053 & 0,110 & 18.631 \\
\hline $88-92$ & 43,13 & 0,705 & 0,060 & 11.702 & $266-270$ & 82,05 & 2,242 & 0,121 & 18.491 \\
\hline $95-100$ & 46,42 & 0,724 & 0,059 & 12.196 & $272-275$ & 81,28 & 2,677 & 0,124 & 21.509 \\
\hline $105-110$ & 50,25 & 0,733 & 0,061 & 12.020 & $276-277$ & 81,59 & 2,045 & 0,109 & 18.764 \\
\hline $115-120$ & 49,45 & 0,756 & 0,062 & 12.156 & $278-280$ & 83,71 & 2,033 & 0,098 & 20.699 \\
\hline $125-130$ & 45,71 & 0,761 & 0,062 & 12.182 & $283-287$ & 83,92 & 2,136 & 0,102 & 20.899 \\
\hline $135-140$ & 47,45 & 0,860 & 0,066 & 13.121 & $288-290$ & 85,39 & 1,624 & 0,087 & 18.636 \\
\hline $145-150$ & 48,23 & 0,860 & 0,069 & 12.385 & $291-295$ & 83,19 & 2,211 & 0,121 & 18.198 \\
\hline $155-160$ & 57,16 & 0,838 & 0,067 & 12.477 & $296-298$ & 85,82 & 1,783 & 0,101 & 17.709 \\
\hline $165-170$ & 59,04 & 0,792 & 0,061 & 12.951 & $298-300$ & 59,14 & 1,777 & 0,091 & 19.447 \\
\hline $175-180$ & 58,54 & 0,863 & 0,066 & 13.074 & $302-307$ & 37,35 & 0,601 & 0,042 & 14.184 \\
\hline $187-192$ & 59,35 & 0,816 & 0,063 & 13.021 & $310-315$ & 35,84 & 0,354 & 0,033 & 10.582 \\
\hline $192-197$ & 62,52 & 1,072 & 0,077 & 13.907 & $320-325$ & 44,74 & 0,289 & 0,025 & 11.681 \\
\hline 203-208 & 64,14 & 1,416 & 0,102 & 13.843 & $330-335$ & 46,33 & 0,263 & 0,023 & 11.682 \\
\hline $214-219$ & 66,36 & 1,408 & 0,110 & 12.849 & $337-342$ & 51,93 & 0,257 & 0,017 & 15.543 \\
\hline
\end{tabular}

Remarkable are the relative high values of organic matter, 1,072-2,677\%, and total nitrogen 0,087 $-0,132 \%$, in the intermediate stratigraphic section indicating more or less anoxic conditions at least in the water/sediment boundary layer. The higher values of the surface sediments correspond to the hypoxia/anoxia conditions of today in the Elefsis Bay. From the carbon and nitrogen data the $\mathrm{C} / \mathrm{N}$ ratio was calculated, which is an indicator of the predominant source of organic matter in aquatic systems (s. Table 2) (Mayer, 1994; Lamb et al., 2006). The C/N ratios of phytoplankton degradation are in general close to 6,7 , while the $\mathrm{C} / \mathrm{N}$ ratios of vascular plants, where the $\mathrm{N}$ is depleted, exceed to 12 . Higher $\mathrm{C} / \mathrm{N}$ ratios indicate that terrestrial material can be the important source for organic matter. During sediment diagenesis the $\mathrm{C} / \mathrm{N}$ ratio can be altered by the selective degradation of the organic matter (Mayer et. al 1994). Typically the $\mathrm{C} / \mathrm{N}$ ratio degreases overtime due to release of $\mathrm{CO}_{2}$ and $\mathrm{CH}_{4}$.

In the study area relative high $\mathrm{C} / \mathrm{N}$ values was calculated, indicating differential decomposition rates for carbon and nitrogen rich compounds, showing more to proteinaceous organic matter decomposition. The average $\mathrm{C} / \mathrm{N}$ value in the sediments of the study core is 14,327 and the values fluctuate from 10,582 to 21,509 . The values in the samples of the $1^{\text {st }}$ stratigraphic section fluctuate from 10,787 to 13,074 , which indicate an environment with vascular plants. In the $2^{\text {nd }}$ stratigraphic section the values range from 12,967 to 21,509 indicating the dominance of a terrestrial source of the organic matter. In the $3^{\text {rd }}$ stratigraphic section values from 10,582 to 15,543 indicate the influence of vascular plants in the aquatic environment. The diagram of the figure 5 shows good correlation for the lower $\mathrm{C} / \mathrm{N}$ values of the $1^{\text {st }}$ and $3^{\text {rd }}$ stratigraphic unit and a scattering of the values of the $2^{\text {nd }}$ stratigraphic unit. 
Important information can be retrieve from the fluctuation values of organic carbon and nitrogen as well as $\mathrm{C} / \mathrm{N}$ ratio in the $2^{\text {nd }}$ stratigraphic unit, indicating alteration of the aquatic condition, probably different fresh water flushing in the semi-closed system.

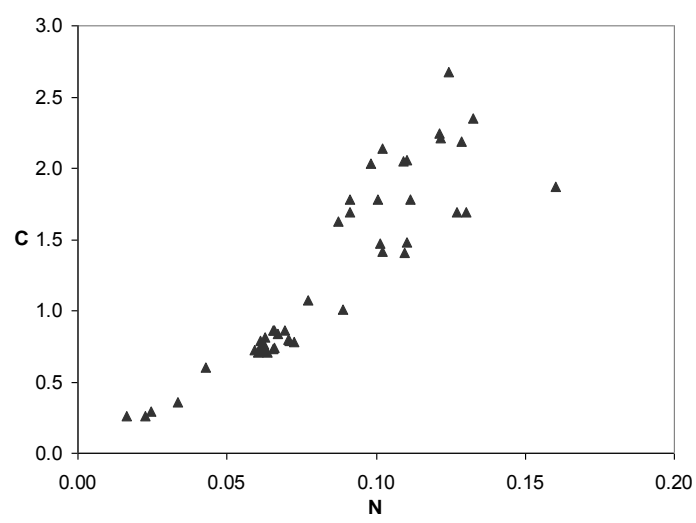

Figure 5 - Correlation of Carbon and Nitrogen contents of the sediment samples of core S-2 Perseus.

Carbonate mineral definition: X-ray diffraction patterns of the sediments, focussed in the carbonate minerals, revealed the presence of calcite, $\mathrm{Mg}$-calcite, aragonite and dolomite. Representative difractogramms are presented in figure 7. Semi quantitative analyses of the difractogrammes, based on the peak intensity of the carbonate minerals, allow us to figure the distribution of the carbonate minerals along the core-profile (Fig 6). The most important fact of the vertical distribution of the carbonate minerals is the domination of the aragonite in the intermediate stratigraphic section.

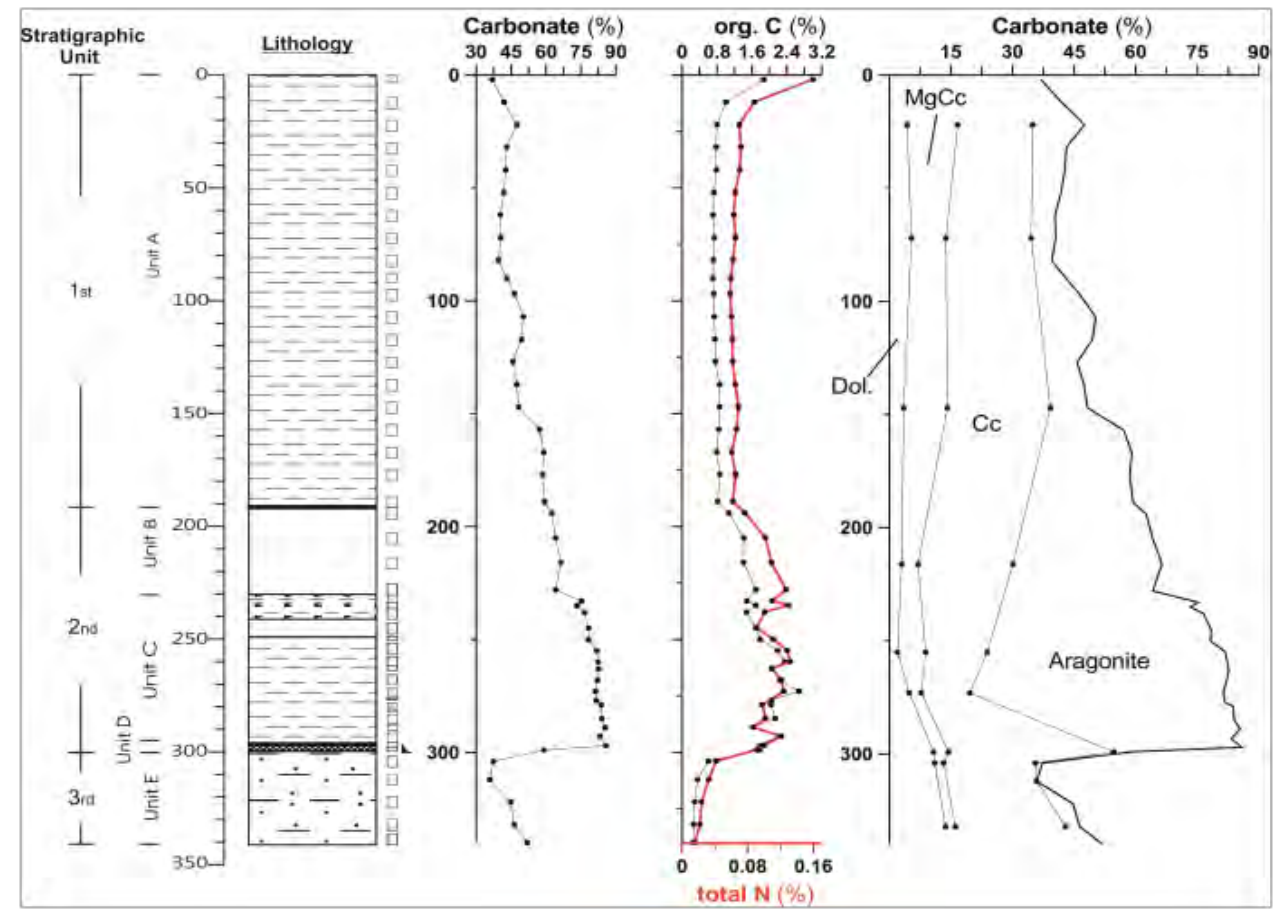

Figure 6 - The vertical distribution of the carbonate, organic carbon, total nitrogen and carbonate minerals $[\mathrm{Cc}=\mathrm{Calcite}, \mathrm{Mg}-\mathrm{Cc}=$ Magnesium calcite, Dol=Dolomite] of the S2 Perseus profile.

$\underline{\text { XLVII, No } 3-1568}$ 


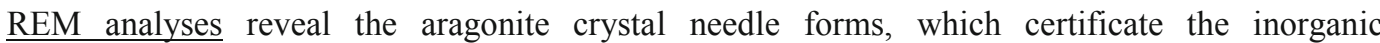
precipitation of calcium carbonate in elongated aragonitic crystals (length of the crystals 3-8 $\mu \mathrm{m}$ ) ( figure 8).

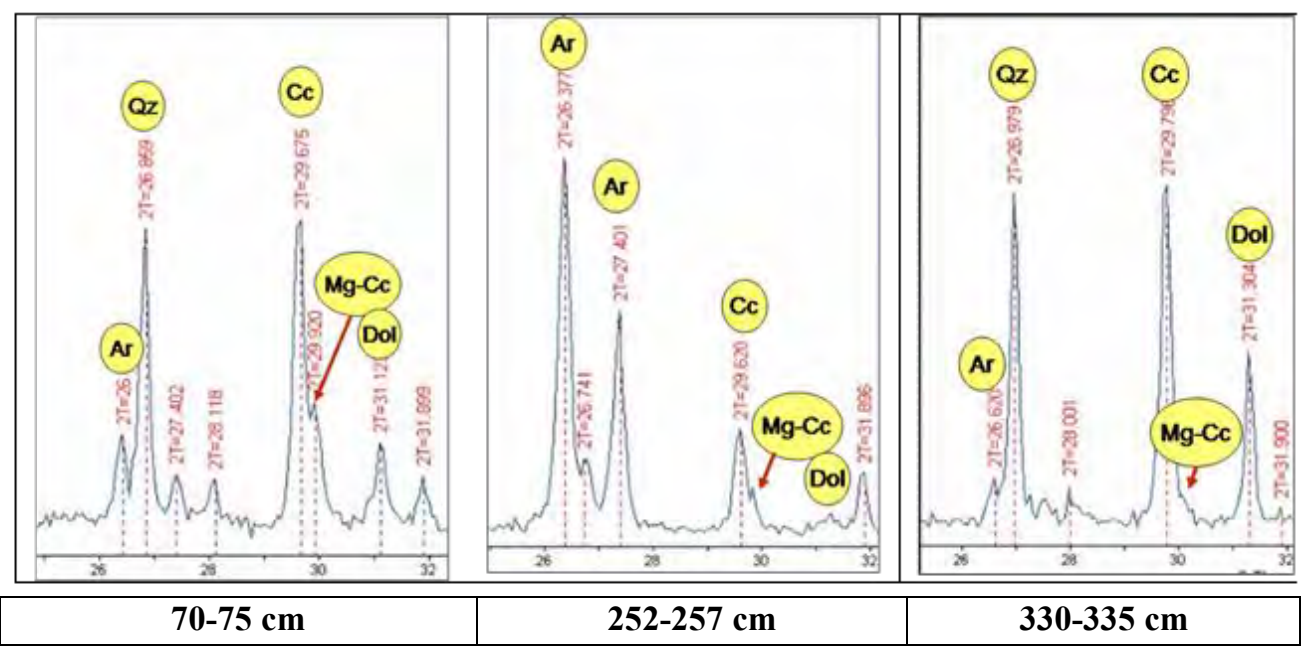

Figure 7 - Representative difractogramms, one from each stratigraphic units, showing the differentiation in the distribution of the carbonate minerals $[Q z=Q u a r t z$, Ar=Aragonite, $\mathrm{Cc}=$ Calcite, $\mathrm{Mg}-\mathrm{Cc}=$ Magnesium calcite, Dol=Dolomite $]$.

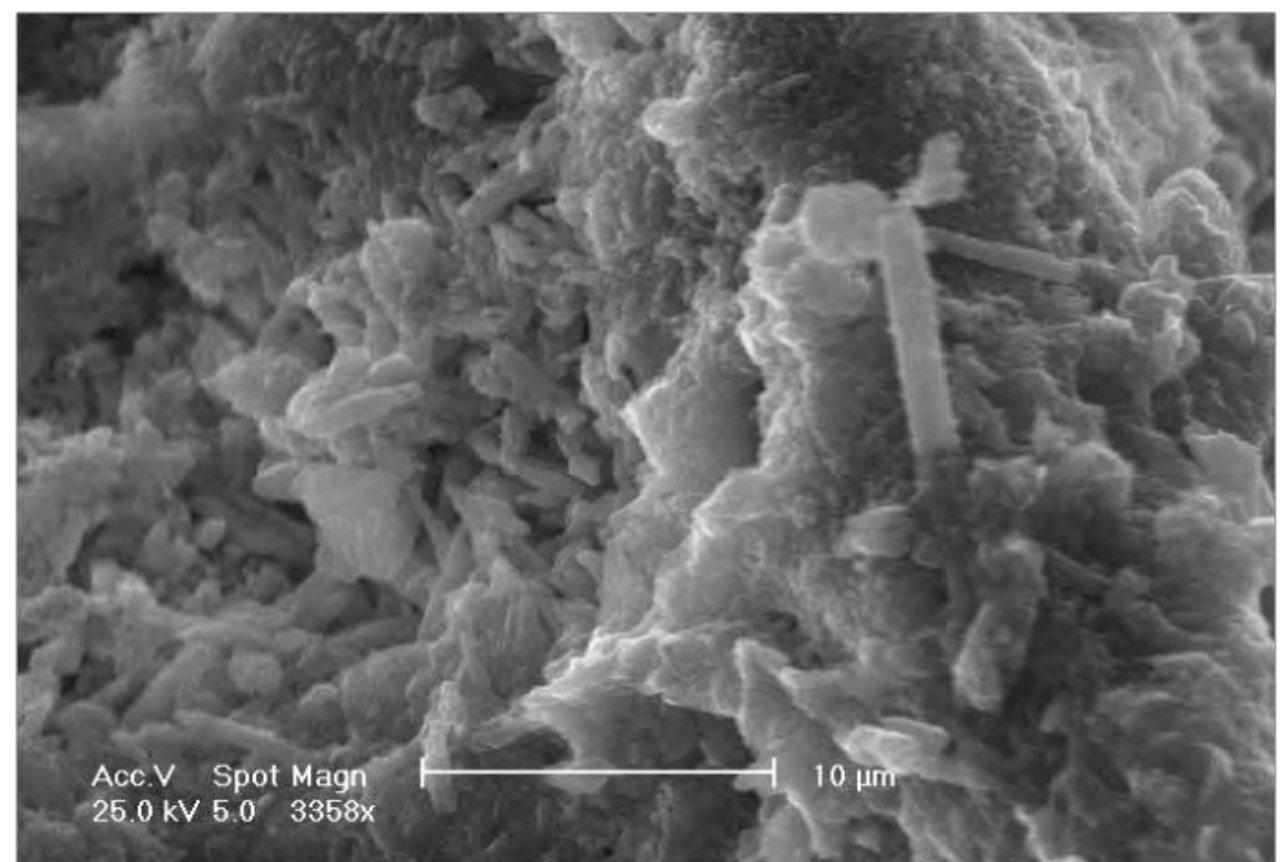

Figure 8 - Aragonite crystal needles certificating inorganic formation of aragonite in the intermediate stratigraphic unit (subsample 252-257 cm).

\section{Discussion}

Based on the macroscopic description of the core as well as on the laboratory results of carbonate content, carbonate differention, organic carbon and nitrogen contents we have attempted to unravel the paleoenviromental evolution of the semi-closed Elefsis Bay. We assume that the fine layer at 
298-300 cm signifies a transgressive event, which separates the freshwater environment of the preexisting fresh water lake ( $3^{\text {rd }}$ stratigraphic section) from the lagoonal environment which follows. At this time the Elefsis Bay connected maybe episodically with the marine environment of the open Saronikos Gulf. The lagoonal-marine environment is recorded in the sediment by the inorganic precipitation of aragonite crystals and corresponds to the second stratigraphic section. Remarkable in this section ( $2^{\text {nd }}$ stratigraphic section) are the relative high values of organic carbon in the sediments, signalizing probably hypoxia/anoxia conditions at least at the water/sediment interface. The fluctuations of the values indicate an unstable system with relative episodic changes in the water column properties (physical, chemical, biological parameters). Results from previous work (Pavlidou et al., 2010), highlighted the fluctuation of the values of organic matter in the core sediments of Elefsis Bay and they are interpreted as anoxia events occurred in Elefsis Bay in the past. These results of the hypoxia/anoxia conditions in the past show us additionally that the occurrence of hypoxia in Elefsis Bay "may not necessarily be attributed to anthropogenic activities but could be naturally driven by oceanographic-climate forcing" (Pavlidou et al. 2010). The abrupt color change at $192 \mathrm{~cm}$ marks the youngest environmental stage of the "normal" marine conditions in the Elefsis bay ( $1^{\text {st }}$ stratigraphic section).

The evolutionary scenario presented is in line with the evolution of the coastline configuration in Greece, which includes several semiclosed gulfs and bays separated from the open sea by shallow sills and which during the LGM where isolated from the open and formed paleolake systems. By rising of the sea level after the glacial retreat (Lambeck \& Pucel, 2005) these areas went flooded with marine water and they changed to marine systems. It is remarkable that the transition of the paleolake system to a marine system is characterized by relatively fast inorganic carbonate precipitation. Regularly these deposits are followed by clastic sedimentation. Such carbonate deposits in the Eastern Mediterranean have been described by Lykousis \& Anagnostou (1993), Richter et al. (1993) for the Saronikos Gulf (Greece), Lykousis et al. (2007) for Gulf of Corinthos (Greece), Sakellariou et al. (2007) for the north Evoikos Gulf (Greece), Karageorgis et al. (2001) Karageorgis et al. (2013) for Pagasitikos Gulf (Greece), Reicher \& Halbach (2007) for the Marmara sea.

The evolutionary dynamic of the Elefsis Bay seems also not to be an isolated event but a part of the general dynamic of the nature. This relative insignificant aquatic subsystem shows rapidly changes from a fresh water system to one saline/ hypersaline and then to a normal marine system.

It is related to the sea level rise.

The inorganic carbonate formation acts mostly as a part of the self-regulation mechanism of the earth system. The formation of the carbonate associations create questions like dolomite vs Aragonite, aragonite vs calcite, etc.

Focusing on the sea level rise we know that the mean sea level during the Last Glacial Maximum (LGM) was approx $120 \mathrm{~m}$ lower than at present. The following question remains at this time without answer, "When the sea intruded into the Elefsis Bay". Elefsis bay was isolated with sills at 2,5-3,0 m depth. Farther investigation will probably help us to answer these questions.

A significant unit of the sediments of Elefsis Bay is the unit with the authigenic aragonite formation. It is assumed that in the semi enclosed aquatic system due to high evaporation aragonite is precipitated. The weather conditions, colt and dry, favored the evaporation.

Another condition for the precipitation of aragonite is the ratio $\mathrm{Mg} / \mathrm{ca}$ which must be $>1$. The variety of the petrography of the area gave probably as weathering products $\mathrm{Mg}$ and $\mathrm{Ca}$.

\section{Conclusion - Further Investigation}

The macroscopic features of the sediments of one core and the laboratory results of sediment analyses, carbonate content, carbonate mineral specification, organic carbon content, were

$\underline{\text { XLVII, No } 3-1570}$ 
important indicators to unravel the paleo-enviromental evolution of the semi-enclosed aquatic system of the Elefsis Bay.

The paleolake environment, followed by the saline/hypersaline state and its transit to the normal marine environment is approached in the frame of this work. Supplementary analyses, micropaleontology and radiocarbon dating are planned in order to concretize the paleoenvironmental evolution of the sensitive coastal embayment of the Elefsis Bay.

\section{References}

Hatzianestis I., Rori N., Sklivagou E. and Rigas F. 2004 PAH profiles in dated sediment cores from Elefsis bay, Greece. Fres Environ Bull 13:1253-1257

Karageorgis A., Kanellopoulos Th., Mavromatis, V., Anagnostou Ch., Koutsopoulou E., Schmidt M., Pavlopoulos, K., Tripsanas, E. and Hallberg R. 2013 Authigenic carbonate mineral formation in the Pagasitikos palaeolake during the latest Pleistocene, central Greece. -GeoMar Lett (2013) 33: 13-29

Karageorgis A.P., Anagnostou Ch. and Michalopoulos P. 2001. Carbonate mineral formation and sea-level changes. Pagassitikos Gulf, Greece, Proceedings of the $5^{\text {th }}$ International Conference on the Mediterranean coastal environment, MEDCOAST, E. Ozhan (Editor), 23-27 October 2001, Hammamet, Tunisia, 1121-1128.

Lamb A. I., Wilson G. P. and Leng M. J. 2006. A review of coastal palaeoclimate and relative sealevel reconstructions using $\delta^{13} \mathrm{C}$ and $\mathrm{C} / \mathrm{N}$ ratios in organic material. Earth-Sci. Rev., 75, 2957.

Lambeck K and Purcell A. 2005. Sea-level change in the Mediterranean Sea since the LGM: model predictions for tectonically stable areas, Quat Sci Rev 24:1969-1988

Lekkas E. 2001. The Athens earthquake (7 September 1999): intensity distribution and controlling factors. Engineering Geology, 59 (2001): 297-311.

Lykousis V, Anagnostou C 1993. Sedimentological and palaeogeographic evolution of Saronikos Gulf during late Quaternary (in Greek, with English Abstract), Bull Geol Soc Greece 28:501-510

Lykousis V, Sakellariou D., Moretti I. and Kaberi H. 2007. Late Quaternary basin evolution of the Gulf of Corinth: sequence stratigraphy, sedimentation, fault-slip and subsidence rates, Tectonophysics 440:29-51

Mayer L. 1994. Surface area control of organic carbon accumulation in continental shelf sediments, Geochim. Cosmochim. Acta, 58, 1271-1284.

Pavlidou A., Kontoyiannis H., Anagnostou Ch., Siokou-Fragkou I., Pagou K. Krasakopoulou E., Assimakopoulou G., Zervoudaki S., Zeri Ch., Chatzianestis J. and Psyllidou-Giouranovits R. 2010. Biochemical characteristics in the Elefsis Bay (Aegean sea, Eastern Mediterranean) in relation to anoxia and climate changes. E.V. Yakushen (ed.), Chemical Structure of Pelagic Redox Interfaces: Observation and Modeling, Hdb Env Chem (2013)22: 161-202, DOI 10.1007/698_2010_55, C Springer - Verlag Berlin Heidelberg 2010 Earth Science Reviews, 52: 1-81. 